\title{
Riscos e Bem-Estar Digital / Risks and Digital Well-Being
}

https://doi.org/10.21814/uminho.ed.36.54

\section{Cristina Ponte}

Faculdade de Ciências Sociais e Humanas da Universidade Nova de Lisboa, Portugal 



\section{Riscos e Bem-Estar Digital}

Os primeiros anos da internet foram marcados pela preocupação com as consequências negativas para as crianças, tanto de conteúdos inadequados como da exposição a predadores. A pressão para políticas europeias em matéria de proteção e segurança deu origem ao Plano Europeu de Ação no início dos anos 2000: Linhas Alerta (hotlines) para reportar conteúdo pornográfico infantil; classificação e filtragem de conteúdos digitais; legislação; autorregulação da indústria e fornecedores da Internet; responsabilização parental sobre conteúdos visionados pelos filhos. Contudo, escasseava um conhecimento robusto e sustentado sobre riscos e segurança digital. As condições para esse conhecimento surgiram com a constituição da rede EU Kids Online, em 2006, a fim de conhecer como as crianças europeias estavam a usar a internet, o que significava para elas esse novo meio em termos de emoções, atitudes e perspetivas, de que modos e para que crianças as práticas de risco resultavam em danos e/ou em oportunidades. Em 2010, a rede realizou o primeiro estudo pan-europeu, em 25 países, com atenção a riscos digitais que marcavam a agenda dos adultos (pornografia, sexting e encontros com estranhos) e cyberbullying. Os resultados deste inquérito respondido por mais de 25 mil crianças e jovens (9-16 anos) derrubariam mitos sobre esse contexto (Livingstone, Haddon, Gorzig \& Ólafsson (2011), pp. 42-43). Com recurso a entrevistas e a grupos de discussão, o conhecimento seria complementado com a atenção aos modos como crianças e jovens entendiam o significado de situações problemáticas online, que sentimentos lhes associavam, o que divergia relativamente às perspetivas de adultos, a importância da mediação familiar e de pares (Smahel \& Wright, 2014). Em 2013-2014, o projeto Net Children Go Mobile identificou de que modos os emergentes dispositivos digitais móveis (tablets e smartphones) estavam a marcar novas práticas, não só digitais, mas também sociais e culturais. Saía-se da agenda estreita focada nos riscos potencialmente danosos para uma agenda que alargava a atenção às oportunidades, competências e direitos e que incluía as crianças e jovens como parceiros de pesquisa.

Em contextos sociais cada vez mais mediatizados, não é mais possível considerar apenas relação das crianças com a internet: importa olhar a relação de crianças e jovens com o mundo mediado pelas tecnologias digitais (Livingstone, Mascheroni \& Staksrud, 2018), compreender que importância 
tem o digital na perspetiva do bem-estar geral da criança, considerando também a sua idade, género, resiliência e outras características. As condições de acesso (cada vez mais disseminadas e ubíquas) e os dispositivos (miniaturizados, individualizados e convergentes) interrelacionam-se com competências, atividades, riscos e oportunidades. 0 contexto digital integra, por sua vez, o contexto social mediado pela família, educadores, pares e comunidade e ambos têm de ter em conta o próprio país, as suas características socioeconómicas e culturais, as condições de provisão e de regulação tecnológica, de educação e conhecimento. Como a pesquisa comparada assinalou, a cultura protecionista e de aversão ao risco dos países do sul europeu traduz-se em formas de mediação parental mais restritiva. É esta matriz plural que precisa de ser convocada quando se considera a relação das crianças com o mundo mediado pelas tecnologias. Na perspetiva do seu bem-estar digital, consideram-se os seus direitos de proteção (como o direito à privacidade), de provisão (como a aquisição de competências e literacias de vária ordem para lidar com os desafios ou de acesso a conteúdos de qualidade adequados à sua idade) e de participação (como o direito a exprimir-se e a ser ouvida). Este enquadramento procura reequilibrar a preocupação com os riscos, dominante nas agendas públicas desde o início, conferindo agora idêntica atenção às oportunidades e às literacias que decorrem do uso da internet. Como tem sido provado nos estudos realizados pela rede Kids Online, na Europa e noutros países (através da rede Global Kids Online), riscos e oportunidades são ambos de ordem probabilística: os riscos podem conduzir a danos, mas também podem estimular a resiliência; as oportunidades podem levar a benefícios, mas para que isso aconteça são necessárias competências - tecnológicas, sociais, criativas, informacionais - que precisam de ser trabalhadas. Esta é sem dúvida uma área de exigente e renovado conhecimento, onde diversos parceiros sociais são convocados e onde as práticas e as vozes de crianças devem ser consideradas. Entre exemplos de instâncias europeias que têm incorporado estas orientações, destaca-se o Guia dirigido aos Estados-membros aprovado pelo Conselho de Ministros do Conselho da Europa, no sentido de estes assegurarem o respeito, a proteção e a realização dos direitos da criança em ambiente digital - CM/Rec (2018)7.

\section{Risks and Digital Well-Being}

The early years of the Internet were marked by the concern about negative consequences for children due to inappropriate content and exposure to predators. 
The pressure to develop European policies related to protection and security resulted in the European Action Plan in the early 2000: hotlines to report child pornographic content; classification and filtering of digital content; legislation; self-regulation of the industry and Internet providers; parental responsibility for content viewed by children.

However, robust and sustainable knowledge about the risks and digital security was rare. The conditions for this knowledge arose with the constitution of the network EU Kids Online, in 2006, in order to learn how European children were using the Internet, what this new medium meant for them in terms of emotions, attitudes and perspectives, in what ways and for which children the risky practices resulted in harm and/or in opportunities. In 2010, the network carried out the first Pan-European study, in 25 countries, with attention to the digital risks of adults' (pornography, sexting and encounters with strangers) and cyberbullying. The results of this survey answered by more than 25 thousand children and young people (9-16 years old) would dismantle myths about this subject (Livingstone, Haddon, Gorzig \& Ólafsson, pp. 42-43).

Using interviews and discussion groups, the knowledge would be complemented taking into account the ways in which children and young people understood the meaning of problematic situations online, what feelings they associated with them, what differed in regard to the perspectives of adults, the importance of family and peer mediation (Smahel \& Wright, 2014). In 2013-2014, the project Net Children Go Mobile identified the ways in which emerging mobile digital devices (tablets and smartphones) were indicating new practices, not only digital but social and cultural as well. This moved beyond the narrow agenda focussing on potentially harmful risks towards an agenda that broadened to consider opportunities, skills and rights and that included children and young people as research partners. In increasingly mediatized social contexts, it is no longer possible to consider only the relationship of children with the Internet: it is important to look at the relationship of children and young people with the world mediated by digital technologies (Livingstone, Mascheroni \& Staksrud, 2018), to understand the importance of the digital aspect in the perspective of the children's well-being, while also considering their age, gender, resilience and other characteristics. The access conditions (increasingly widespread and ubiquitous) and the devices (miniaturized, individualized and convergent) are linked to the skills, activities, risks and opportunities. The digital context combines, in turn, the social context mediated by family, educators, peers and the community and both have to take into account the country 
itself, its socio-economic and cultural characteristics, the conditions of provision and technological regulation, education and knowledge.

As comparative research has pointed out, the protectionist and risk-averse culture of southern European countries translates into more restrictive forms of parental mediation. It is this plural matrix that needs to be called upon when considering the relationship of children with the world mediated by technologies. From the perspective of their digital well-being, one must consider their rights of protection (such as the right to privacy), of provision (such as the acquisition of skills and literacies of various kinds to deal with challenges or access to quality content considered appropriate to their age) and of participation (such as the right to express themselves and to be heard).

This framework seeks to rebalance the concern about risks, which has dominated public agendas since the beginning, with equal attention being given now to the opportunities and literacies that result from the use of the Internet. As has been proven in studies carried out by the Kids Online network, in Europe and in other countries (through the Global Kids Online network), risks and opportunities are both probabilistic: risks can lead to damage, but they can also stimulate resilience; opportunities can lead to benefits, but for that to happen, the necessary skills - technological, social, creative, informational - need to be worked on. This is undoubtedly an area of demanding and renewed knowledge where several social partners are required and where children's practices and voices must be considered.

Among examples of European bodies that have incorporated these guidelines, the Guide for Member States approved by the Council of Ministers of the Council of Europe stands out in the sense that it ensures the respect, protection and realization of children's rights in the digital environment CM/Rec(2018)7.

\section{Referências / References}

Livingstone, S., Anke Gorzig, L. H. \& Ólafsson, K. (2011). Final Report EU Kids Online II. Deliverable for the EC Safer Internet Programme (pp. 42-43). ISSN 2045-256X.

Livingstone, S., Mascheroni, G. \& Staksrud, E. (2018). European research on children's internet use: assessing the past and anticipating the future. New Media and Society, 20 (3). pp. 1103-1122 .

Smahel, D. \& Wright, M. (eds) (2014). The meaning of online problematic situations for children. Results of a qualitative cross-cultural investigation in nine European countries. London: EU Kids Online, London School of Economics and Political Science. www.eukidsonline.net 